\title{
Dress Culture-Related Adaptation Problems Faced by Turkish Women Living Abroad
}

\author{
Associate Professor Emine Koca \\ Research Assistant Inci Seda Kivilcimlar Sahin \\ Art and Design Faculty,Fashion Design Department, \\ Gazi University, Golbasi Campus, Turkey
}

doi: 10.19044/esj.2017.v13n5p15 URL:http://dx.doi.org/10.19044/esj.2017.v13n5p15

\begin{abstract}
This study, which was carried out in order to identify the problems faced by Turkish women living abroad with respect to dress culture, is a descriptive study based on a scan model. The sample group for this study comprised 394 Turkish women aged 20 and over living in London in the United Kingdom, which is home to many cultures as well as its own specific culture. As a result of an analysis of the data obtained from the survey prepared by the researcher it was determined that people coming to London from the major cities in Turkey encountered fewer problems with respect to dress culture than people coming from towns and villages in Turkey, and that people with an income of less than $£ 1,000$ a month experienced more problems than people with a higher level of income. Furthermore, it was also determined that the sample group aged 50 and over experienced more adaptation problems with respect to dress culture, and that these problems were generally due to the length of clothing and how revealing it was.
\end{abstract}

Keywords: Dress culture, clothing, adaptation problems, Turks living abroad

\section{Introduction}

Clothing and style of attire are an important factor in any civilization's cultural makeup and they are just as much the cultural building blocks for nations today as they have been throughout history. Styles of attire are shaped by such societal values as tradition, custom and lifestyle. Over time they become a part of society's culture by creating that society's dress culture through the values they reflect. Although the history of dress culture dates back a long time it nevertheless undergoes transformation from one generation to the next just like other cultural values do. In addition to their primary function of protection clothing and attire have become symbols 
reflecting their society's values due to their characteristic of being able to indicate personality and status. Therefore, it can be said that dress culture documents the advance of human history.

Styles of attire are shaped by societies' lifestyles. Influenced by many factors they have undergone changes over the course of history while today in addition to being a cultural element, due to fashion's powerful influence they have even created their own sector. How fashion can and does influence people is a topic that has been discussed from different perspectives by many intellectuals. Simmel (1904) stated that fashion met people's need for singularity and difference as well as the desire for unity and similarity (from Ritzer, 1992). Meanwhile, Bursaligil (2009:3) described fashion as a means of identifying social status due to its hierarchical aspects, as a device for erotic attraction due to its sexuality aspects, and as the flaunting of wealth due to its economic aspects.

It is known that fashion, which is equated with clothing, is an important factor in clothing preferences. The reason why fashion holds the masses under its sway despite being fleeting and seasonal stems from its inherent originality and its quality as a social phenomenon (Koca,Vural and Koç, 2013:56). Regardless how it is described, it is an indisputable fact that fashion is a developing social phenomenon influenced by individual preferences and cultural events. Just as society's living conditions, beliefs and cultural values determined how that society dressed in the past, today the social, political, artistic and cultural events of not just one society but all the other societies it is in contact with shape fashion by creating trends. Trends possessing the characteristic of reflecting many social phenomena can and do shape fashion, and this explains fashion's characteristic of being a social phenomenon. Even though they know that fashion is a vehicle for rapid consumption individuals nevertheless try to follow fashion in order to conform to society and sometimes even to catch the latest trends. While doing this they mostly tend to follow fashion while at the same time preserving the values they possess. As a result, fashion trends that are seen across the entire world at the same time can and do reflect styles of attire, and they create dress culture by being interpreted in such as a way as to carry different meanings in different cultures.

Dress culture is described as a phenomenon common to all mankind and it is a part of cultural makeup. This plus the styles of attire that make up this culture are the leading visual objects that help to identity the people that create them plus their societies due to their unique identities in specific areas. Just as the cultural globalization of this modern age is the reason for lifestyles becoming different in every field it has also led to changes in dress culture, but even so it is difficult for individuals to learn to abandon longadopted values. It is well known that people who have to live in societies 
possessing different cultures encounter important problems in this area. As Bursaligil (2009:2) pointed out, individuals are unable to step outside the dress culture and style of attire that has been shaped over time by the value judgments of the society they belong to, or they find it very difficult to do so.

The opinion that the same cultural products carry different meanings for different groups and masses is valid for almost every product that is the expression of modern culture (Koc, 2008:107). The effects and consequences of cultural globalization vary depending on how close the local culture is to current global values, its flexibility and its ability to resist. While rejection of one's own culture and complete adherence to global culture or conversely turning one's back on the world and staying rigidly within one's own culture are seen as extreme reactions, nations feel the need for syntheses that will enable them to merge with world values while not losing their own cultural values. For those cultures that are lucky enough to live within the global culture without losing their own characteristics there is also the means to form their own regional and communications networks at an international level using the global system's technology (Ozkan, 2006: 78).

It can be said that from the past to the present the styles of attire in every society and social class having different lifestyles and cultures have also demonstrated differences, and that other factors in addition to fashion have played an important role in these differences. Dress changes according to fashion and valid preferences as much it does according to purpose of use, the age of the individual and socio-economic status (Koca, 2008: 175). When the new items that are introduced by fashion are viewed from the context of culture you can see social and regional differences in the acceptance of the new over the old that it is replacing. A prime example of a new form of clothing being altered to comply with the society or region in which it is worn can be seen in the wearing of trousers underneath skirts that were of a length not in keeping with social values in various parts of Anatolia when the mini-skirt came into fashion. This difference constitutes an important problem for people who have to spend a part of their lives in different cultures. The individual wants to fit in with the current prevailing culture while at the same time feeling the need to preserve their own identity. Problems created by concerns about losing one's own identity emerge during this time. According to Pehlivan (2007: 271), these differences include the individual's own culture and a clash of cultures, a lack of borders and the lack of a sense of belonging. Pehlivan calls this condition hybrid culture. This hybrid culture can be particularly harrowing for young individuals. This is because young people find it difficult to splice their parents' way of life with this new world. They feel pressurized and they experience a clash of cultures. 
A person who has grown up in Anatolian culture with a native form of attire can and does find it hard to adjust when they see the different clothes and complementary accessories and shoes in the country they have emigrated to. They begin to combine these clothes, which they have never seen before, with their own dress culture very slowly and wear clothes in a manner that can be said to be neither culture one nor the other. The efforts by people and the groups they are a part of to stand out are the reason why fashion advances within a specific cycle. Accordingly, lower social groups adopt the principle of "mimicry" and they adapt the clothing worn by higher social groups to fit themselves, and thus they try to forge new statuses (Ozelge, 2008:71).

When it is considered that people who determine their style of attire according to one dress culture experience adaptation problems with respect to dress culture when they have to live in other cultures, particular in international cultures, then in order to keep the problems to a minimum the synthesis between the two cultures needs to be made correctly. In this study, which was precipitated by this thought, the aim is to identity the adaptation problems experienced by Turkish women living abroad with respect to dress culture.

To this end in general answers were sought to the following questions:

1. Do Turkish women living abroad experience adaptation problems with respect to attire?

2. Do Turkish women living abroad think that their manner of attire affects their social life?

\section{Method and Sampling}

The necessary permissions were obtained from the Republic of Turkey Embassy in London in order to identify the sample group for this study, which aims to identify the adaptation problems experienced by Turkish women living abroad with respect to dress culture. The study focused on such districts as Enfield, Barnet, Haringey, Islington and Hackney, which are areas with high concentrations of Turks. The demographic characteristics of the sample group, which is made up of 394 Turkish women aged 20 and over living in London and chosen at random, are presented in Table 1. 
Table 1. Demographic Characteristics of Sample Group

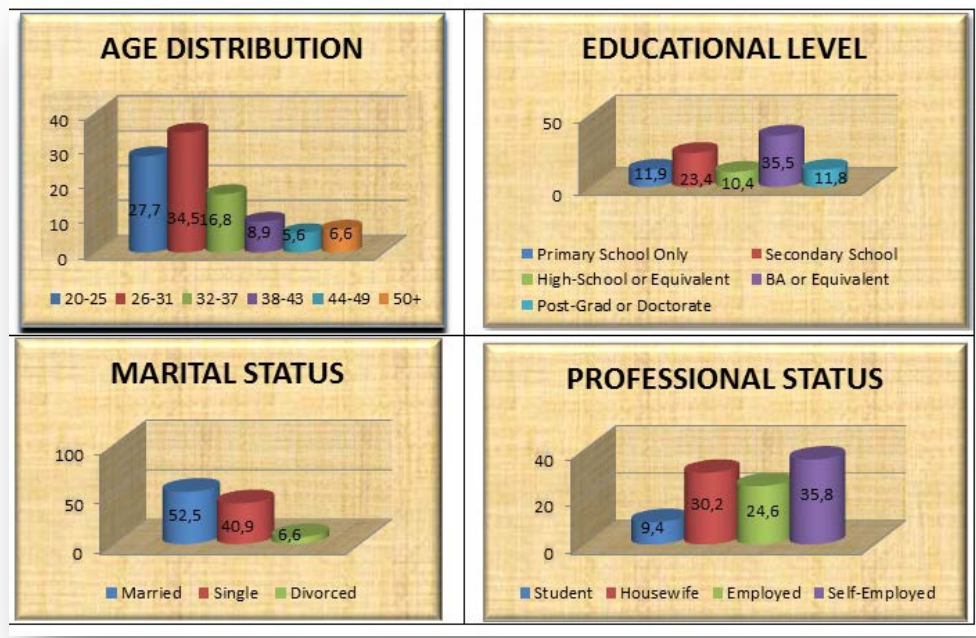

A questionnaire prepared by the researchers was used to gather the research data. The questionnaire asked questions about the sample group's demographic characteristics, style of attire, the changes in their style of attire after they began living in London, the problems they encountered as well as the problems they encountered with respect to style of attire when they returned to Turkey. The questionnaire was tested for validity and reliability. With a Cronbach Alpha value of 0.700 the questionnaire is seen to be quite reliable.

The collected data was analyzed using SPSS 17.00 (Statistical Package for Social Sciences). The data was presented in the form of frequency tables as well as table of results from Chi-Square tests and Kruksal Wallis $\mathrm{H}$ tests. After the Kruksal Wallis $\mathrm{H}$ test a Mann-Whitney-U test was applied to the variables in pairs in order to determine which group the differences in the variables originated from. The results were then interpreted.

\section{Findings and Interpretation}

The change that emerges when the impact of cultural globalization affects local culture as well varies depending on individuals' ability to hold onto their values. While this situation is felt at home, it is felt even more in people who have to live in different societies, and this creates a problem. It is known that some people are able to break away easily from their own culture and adapt to new values while others experience problems as they try to find their place between two cultures in an effort not to lose their cultural values, and that this is affected by demographic characteristics. 
The factors that make consumers purchase particular products in the field of clothing, a field that nowadays has taken on multiple personal and social aspects that go beyond simple need, are many and various, and are influenced by diverse variables (Koca and Koç, 2016: 235).The spread of the dress culture-related adaptation problems experienced by the sample group can be seen in the tables between Table 2 and Table 15 .

Table 2 - Encountered Dress Culture-Related Adaptation Problems by Age Distribution

\begin{tabular}{cccc}
\hline & Age & $\mathrm{n}$ & Mean Rank \\
\hline Circumstances when & $20-25$ & 109 & 192.12 \\
Turkish women living & $26-31$ & 136 & 202.10 \\
abroad experience dress & $32-37$ & 66 & 202.89 \\
culture-related adaptation & $38-43$ & 35 & 195.13 \\
problems. & $44-49$ & 22 & 260.70 \\
& 50 plus & 26 & 131.98 \\
& & & \\
\hline
\end{tabular}

According to the results of the Kruksal Wallis $\mathrm{H}$ Test seen in Table 2, it was determined that people aged 50 and over experienced problems relating to dress culture when living in London. It may be said that people aged 50 and over are stronger than the younger generations given their cultural makeup and life experiences and that accordingly they hold fast to a certain dress culture, which in turn affects the outcome of the test. The group that followed them in experiencing adaptation problems was the 20-25 age group. Akyol (2010: 187) said: "When young people generate their identity they take a great interest in those around them and what they think of them. Young people look to popular, successful people or their peers and want to be like them; they try to emulate them in every way." It can be seen that wants and expectations that develop with age are influential when individuals choose from among a vast variety of products and services all meeting their needs.

In many age-related studies it has been seen that young people are very fickle in their preferences when compared to adults, who demonstrate more rigid behavior. Koca and Koc (2010:39) state that an individual's identity among his or her peers in important during teenage years. Pointing out that dress plays an important part in this developmental process they state that during this period, which is known as the stormy period, young people try to establish their own identity while at the same time striving to be socially acceptable. While young people are more open to change the pressure put on them by their family elders can and does lead to them experiencing a cultural crisis. In addition, one result that stands out from this test is that it is the upper and lower age groups that experience adaptation difficulties with respect to dress culture. 
Table 3 - Dress Culture-Related Adaptation Problems by Age

(The Mann-Whitney U-Test was applied because the relevant Kruksal Wallis Test's level of

\begin{tabular}{|c|c|c|c|}
\hline \multicolumn{2}{|c|}{ Age } & $\begin{array}{c}\text { Dress Culture-Related } \\
\text { Adaptation Problems } \\
\text { Experienced by Turkish Women } \\
\text { Living Abroad }\end{array}$ & $\begin{array}{l}\text { Dress Culture-Related } \\
\text { Adaptation Problems } \\
\text { Experienced by Turkish } \\
\text { Women Returning Home } \\
\text { From Abroad }\end{array}$ \\
\hline \multirow{5}{*}{$20-25$} & $26-31$ & 0.507 & 0.004 \\
\hline & $32-37$ & 0.526 & 0.064 \\
\hline & $38-43$ & 0.888 & 0.009 \\
\hline & $44-49$ & 0.011 & 0.000 \\
\hline & 50 plus & 0.018 & 0.029 \\
\hline \multirow{4}{*}{ 26-31 } & $32-37$ & 0.995 & 0.658 \\
\hline & $38-43$ & 0.738 & 0.485 \\
\hline & $44-49$ & 0.023 & 0.020 \\
\hline & 50 plus & 0.004 & 0.752 \\
\hline \multirow{3}{*}{$32-37$} & $38-43$ & 0.733 & 0.366 \\
\hline & $44-49$ & 0.039 & 0.021 \\
\hline & 50 plus & 0.005 & 0.671 \\
\hline \multirow{2}{*}{$38-43$} & $44-49$ & 0.016 & 0.118 \\
\hline & 50 plus & 0.016 & 0.751 \\
\hline $44-49$ & 50 plus & 0.000 & 0.075 \\
\hline
\end{tabular}

significance was 0.006 for adaptation problems experienced while living abroad but 0.001 for adaptation problems experienced on return to Turkey.)

According to the Mann-Whitney U-Test results in Table 3, a significant difference was noticed between women living abroad aged 44-49 and the women in the other age groups (20-25, 26-31, 32-37, 38-43 and 50plus) with respect to dress culture adaptation problems whereas on return to Turkey a significant difference with respect to dress culture adaptation problems was seen between the women aged 20-25 and the other groups, and between the women aged 44-49 and the women in the groups aged 26-31 and 32-37.

Table 4 - Dress Culture-Related Adaptation Problems by Level of Education

\begin{tabular}{cccc}
\hline & Level of Education & n & MeanRank \\
\hline Dress Culture-Related Adaptation & Primary School only & 47 & 137.06 \\
Problems Experienced by Turkish & Secondary School & 92 & 177.37 \\
Women Living Abroad & High School or & 41 & 185.15 \\
& equivalent & 140 & 225.62 \\
& BA or equivalent & 74 & 214.55 \\
& Post-Grad or Doctorate & 74 & $\mathbf{3 9 4}$ \\
\hline
\end{tabular}


When the results of the Kruksal Wallis $H$ Test in Table four are analyzed is can be seen that the group that experienced the most dress adaptation problems after starting to live in London was the group having only a primary school level of education with 137.06 points. The group ranking second was those having a BA or equivalent level of education with 225.26 points.

The results of the Mann-Whitney $U$ Test that was applied to the variables in pairs in order to determine which groups the difference between the variables originated from following the Kruksal Wallis Test can be seen in Table 5.

Table 5 - Dress Culture-Related Adaptation Problems by Education Level

Education Level Dress Culture-Related Adaptation Problems Experienced by Turkish Women Living Abroad

\begin{tabular}{ccc} 
& Secondary School & 0.038 \\
Primary & High School & 0.022 \\
School & BA & 0.000 \\
\hline & Post Grad or Doctorate & 0.000 \\
Secondary & High School & 0.706 \\
School & BA & 0.001 \\
\hline \multirow{3}{*}{ High School } & Post Grad or Doctorate & 0.033 \\
\hline & BA & 0.033 \\
\hline BA & Post Grad or Doctorate & 0.162 \\
\hline
\end{tabular}

(The results of the relevant Kruksal Wallis Test show the level of significance for Dress Cultre-Related Adaptation Problems Experienced by Turkish Women Abroad is 0.000 , meaning there is a difference in the averages. A Mann Whitney $U$ test was applied in order to identify which groups the difference was between. As the figure for Adaptation Problems Experienced by Turkish Women on Return to Turkey After Having Lived Abroad was 0.445 it was concluded that there was no difference. Therefore, there is no need to apply the Mann Whitney U Test to determine which group is different.)

When Table 5 is analyzed a significant difference can be seen between women of primary school only education living abroad and women having secondary school, high school and post-graduate education; a significant difference can be seen between women having a secondary school education and women with a BA or a post graduate or doctorate level of education, and also between high-school graduates and BA graduates with respect to dress culture-related adaptation problems. 
Table 6. Distribution of Dress Culture-Related Adaptation Problems by Marital Status

\begin{tabular}{cccc}
\hline Marital Status & $\mathrm{n}$ & Mean Rank \\
\hline & Married & 207 & 185.62 \\
Dress Culture-Related Adaptation Problems & Single & 161 & 215.02 \\
Experienced by Turkish Women Living & Divorced & 26 & 183.60 \\
Abroad & Total & \multicolumn{2}{c}{394} \\
\hline
\end{tabular}

According to the results of the Kruksal Wallis $\mathrm{H}$ Test in Table 6, it can be seen that married women then divorced women experienced the most dress culture-related adaptation problems when they started living in London with 185.62 and 183.60 points respectively.

Table 7 - Dress Culture-Related Adaptation Problems by Marital Status

\begin{tabular}{ccc}
\hline Marital Status & Dress Culture-Related Adaptation Problems Experienced by Turkish \\
& \multicolumn{2}{c}{ Women Living Abroad } \\
\hline Married & Single & 0.013 \\
Married & Divorced & 0.911 \\
Single & Divorced & 0.199 \\
\hline
\end{tabular}

(The results of the relevant Kruksal Wallis Test give the level of significance for Dress Culture-Related Adaptation Problems Experienced by Turkish Women Living Abroad as 0.038, which means there is a difference between the averages. A Mann Whitney U Test was applied to determine between which groups the difference was. As the figure for Adaptation Problems Experienced by Women on Retunr to Turkey After Having Lived Abroad was 0.115 it was concluded that there was no difference, and so a Mann Whitney U Test was not necessary.)

When the results of the Mann Whitney $U$ Test in Table 7 are analyzed it can be seen that there is a considerable difference between married and single Turkish women living abroad with respect to dress culture-related adaptation problems.

Table 8 - Dress Culture Related Adaptation Problems by Employment Status

\begin{tabular}{cccc}
\hline Employment Status & & $\mathrm{n}$ & Mean Rank \\
\hline & Student & 37 & 230.11 \\
& Housewife & 119 & 167.44 \\
Dress Culture-Related Adaptation Problems & Employed & 97 & 217.53 \\
Experienced by Turkish Women Living Abroad & Self-employed & 141 & 200.54 \\
& Total & & 394 \\
\hline
\end{tabular}

According to the results of the Kruksal Wallis $\mathrm{H}$ Test in Table 8, the sample group that experienced the most adaptation problems with respect to dress culture was housewives with 183.6 points while the group that experienced the fewest problems was students with 230.11 points. 
Table 9- Dress Culture-Related Adaptation Problems by Employment Status

\begin{tabular}{|c|c|c|}
\hline \multicolumn{2}{|c|}{ Employment Status } & $\begin{array}{l}\text { Dress Culture-Related Adaptation Problems } \\
\text { Experienced by Turkish Women Living }\end{array}$ \\
\hline \multirow{3}{*}{ Student } & Housewife & 0.003 \\
\hline & Employed & 0.579 \\
\hline & Self Employed & 0.172 \\
\hline \multirow{2}{*}{ Housewife } & Employed & 0.001 \\
\hline & Self Employed & 0.019 \\
\hline Employed & Self Employed & 0.241 \\
\hline
\end{tabular}

(The results of the relevant Kruksal Wallis Test give the level of significance for Dress Culture-Related Problems Experienced by Turkish Women Living Abroad as 0.002 meaning there is a difference between the averages. A Mann Whitney $U$ test was applied to determine between groups this difference was. As the figure for Adaptation Problems Experienced by Women on Return to Turkey After Having Lived Abroad was 0.839 it was concluded that there was no difference, and so a Mann Whitney U Test was not necessary.)

According to the results of the Mann Whitney U Test in Table 9 a statistically significant difference can be seen between housewives living abroad and students, employed and self-employed women.

Table 10 - Dress Culture-Related Adaptation Problems by Income

\begin{tabular}{cccc}
\hline Income Level & & $\mathrm{n}$ & Mean Rank \\
\hline & Less than $£ 1,000$ & 17 & 155.76 \\
& $£ 1,000-£ 2,000$ & 226 & 180.77 \\
Dress Culture-Related Adaptation Problems & $£ 2,001-£ 3,000$ & 68 & 235.73 \\
Experienced by Turkish Women Living Abroad & $£ 3,001-£ 4,000$ & 40 & 220.36 \\
& $£ 4,000$ and over & 43 & 220.20 \\
& Total & & 394 \\
\hline
\end{tabular}

When the results of the Kruksal Wallis $\mathrm{H}$ Test in Table 10 are analyzed is can be seen that the group experiencing the most dress culturerelated adaptation problems on moving to a foreign country was the group having an income of less than $£ 1,000$ a month with a ratio of 155.76. It is understood that income is an important factor in adapting to dress culture and that low income people have greater difficulty in adapting. In order to determine which groups the difference in the variable originated from a Mann Whitney U Test was applied to the variables in pairs and the results presented in Table 11. 
Table 11 - Dress Culture Adaptation Problems by Level of Income

\begin{tabular}{|c|c|c|c|}
\hline \multicolumn{2}{|c|}{ Level of Income } & $\begin{array}{l}\text { Dress Culture-Related } \\
\text { Adaptation Problems } \\
\text { Experienced by Turkish } \\
\text { Women Living Abroad }\end{array}$ & $\begin{array}{l}\text { Dress Culture-Related } \\
\text { Adaptation Problems } \\
\text { Experienced on Return to } \\
\text { Turkey by Turkish Women } \\
\text { Having Lived Abroad }\end{array}$ \\
\hline \multirow{4}{*}{$\begin{array}{c}£ 1,000- \\
£ 2,000\end{array}$} & $\begin{array}{l}£ 2,001- \\
£ 3,000\end{array}$ & 0.000 & 0.753 \\
\hline & $\begin{array}{l}£ 3,001- \\
£ 4,000\end{array}$ & 0.040 & 0.064 \\
\hline & $\begin{array}{c}£ 4,000 \text { and } \\
\text { over }\end{array}$ & 0.043 & 0.000 \\
\hline & $\begin{array}{c}£ 1,000 \text { or } \\
\text { less }\end{array}$ & 0.423 & 0.873 \\
\hline \multirow{3}{*}{$\begin{array}{l}£ 2,001- \\
£ 3,000\end{array}$} & $\begin{array}{c}£ 3,001- \\
£ 4,000\end{array}$ & 0.476 & 0.194 \\
\hline & $\begin{array}{c}£ 4,000 \text { and } \\
\text { over }\end{array}$ & 0.576 & 0.001 \\
\hline & $\begin{array}{l}£ 1,000 \text { or } \\
\text { less }\end{array}$ & 0.005 & 0.756 \\
\hline \multirow{2}{*}{$\begin{array}{l}£ 3,001- \\
£ 4,000\end{array}$} & $\begin{array}{c}£ 4,000 \text { and } \\
\text { over }\end{array}$ & 0.945 & 0.031 \\
\hline & $\begin{array}{c}£ 1,000 \text { or } \\
\text { less }\end{array}$ & 0.037 & 0.224 \\
\hline $\begin{array}{c}£ 4,000 \text { and } \\
\text { over }\end{array}$ & $\begin{array}{c}£ 1,000 \text { or } \\
\text { less }\end{array}$ & 0.052 & 0.006 \\
\hline
\end{tabular}

(The results of the relevant Kruksal Wallis Test give the level of significance for Dress Culture-Related Adaptation Problems Experienced by Turkish Women Living Abroad as 0.001, and so a Mann-Whitney U Test was applied.)

When Table 11 is analyzed a significant difference can be seen between Turkish women living abroad with an income of $£ 1,000-£ 2,000$ and those women with incomes in the $£ 2,001-£ 3,000, £ 3,001-£ 4,000$ and $£ 4,000$ plus brackets, also between those earning $£ 2,001-£ 3,000$ and those on $£ 1,000$ or less, and those women earning $£ 3,001-£ 4,000$ and those on $£ 1,000$ or less with respect to dress culture related adaptation problems. On their return to Turkey on the other hand, significant differences were identified between women with an income of $£ 1,000$ or less and those women with incomes in the higher income brackets. Koca's (2008) study comparing how students in different countries regard fashion showed that income was the most important factor in how students regard fashion, and the results in Table 11 are in parallel with those findings. 
Table 12 - Dress Culture-Related Adaptation Problems by Size of Settlement Area in Turkey

\begin{tabular}{cccc}
\hline & $\begin{array}{c}\text { Settlement Area in } \\
\text { Turkey Before } \\
\text { Moving to London }\end{array}$ & n & Mean Rank \\
\hline Dress Culture-Related Adaptation & Metropolitan & 266 & 214.35 \\
Problems Experienced by Turkish & Province & 59 & 164.02 \\
Women Living Abroad & District & 39 & 166.74 \\
& Town or Village & 30 & 153.93 \\
& Total & & $\mathbf{3 9 4}$ \\
\hline
\end{tabular}

According to the results of the Kruksal Wallis $\mathrm{H}$ Test in table 12, the sample group that lived in towns or villages before moving to London experienced the most adaptation problems with respect to dress culture with 153.93 points followed closely by those who lived in the provinces and districts. It can be said that those who lived in the metropolitan cities experienced fewer problems or no problems with respect to dress culture. Even those women living outside the metropolitan cities experience dress culture-related problems. Results in Demir's (2006) study called "Young Girls' Media Consumption in the Other Turkey" show that young girls from Elazığ do not take to the lifestyles shown on TV that are a long way from their own culture, and these results support this conclusion.

Table 13 - Dress Culture Adaptation Problems by Settlement Area in Turkey

\begin{tabular}{|c|c|c|c|}
\hline \multicolumn{2}{|c|}{$\begin{array}{l}\text { Settlement Area in Turkey } \\
\text { Before Moving Abroad }\end{array}$} & $\begin{array}{c}\text { Dress Culture-Related } \\
\text { Adaptation Problems } \\
\text { Experienced by } \\
\text { Turkish Women } \\
\text { Living Abroad }\end{array}$ & $\begin{array}{c}\text { Dress Culture-Related Adaptation } \\
\text { Problems Experinced by Turkish } \\
\text { Women on Return to Turkey After } \\
\text { Having Lived Abroad }\end{array}$ \\
\hline \multirow{3}{*}{$\begin{array}{l}\text { Metropolitan } \\
\text { City }\end{array}$} & Province & 0.002 & 0.009 \\
\hline & District & 0.013 & 0.006 \\
\hline & $\begin{array}{l}\text { Town or } \\
\text { Village }\end{array}$ & 0.006 & 0.671 \\
\hline \multirow[b]{2}{*}{ Province } & District & 0.867 & 0.453 \\
\hline & $\begin{array}{l}\text { Town or } \\
\text { Village }\end{array}$ & 0.692 & 0.248 \\
\hline District & $\begin{array}{l}\text { Town or } \\
\text { Village }\end{array}$ & 0.600 & 0.161 \\
\hline
\end{tabular}

(The results of the relevant Kruksal Wallis Test give the level of significance for Dress Culture-Related Adaptation Problems Experienced by Turkish Women Living Abroad as 0.000, and so a Mann-Whitney U Test was applied.)

When the results of the Mann Whitney $\mathrm{U}$ Test that was applied to determine which groups the difference between the variable originated from are examined it can be seen that there is a significant difference between those Turkish women living abroad who used to live in the metropolitan 
cities and those who used to live in the provinces, districts, towns and villages. It can be seen from Table 13 that there is a significant difference between women who live in the metropolitan cities and those who live in the provinces and districts on return to Turkey.

Table 14 - Dress Culture-Related Problems by Settlement Area in London

\begin{tabular}{cccc}
\hline & & $\mathrm{n}$ & Mean Rank \\
\hline Settlement Area in London & Wood Green & 22 & 158.48 \\
& Enfield & 37 & 212.59 \\
& Camden & 37 & 180.42 \\
& Hackney & 22 & 210.00 \\
& Islington & 26 & 186.77 \\
Dress Culture-Related Adaptation & Tottenham & 23 & 165.41 \\
Problems Experienced by Turkish & S.Kensington & 21 & 229.83 \\
Women Living Abroad & Palmers Green & 15 & 209.40 \\
& Central & 38 & 250.62 \\
& Wandsworth & 38 & 170.14 \\
& Surrey & 39 & 215.65 \\
& Edmonton & 20 & 184.80 \\
& Elephant \&Castle & 11 & 146.36 \\
& Mill Hill & 10 & 258.10 \\
& Finchley-Woodside Park & 35 & 178.64 \\
\hline
\end{tabular}

According to the results of the Kruksal Wallis H Test, it can be seen that the sample groups living in such districts as Elephant and Castle (146.36), Wood Green (158.48) and Tottenham (165.41) where Turks mainly reside experienced proportionally more problems than in other districts. It can be said that the group living in the Mill Hill district experienced the fewest problems with 258.10 points.

Mill Hill is a neighborhood within the Barnet Municipal District. In a study relating to the Barnet Municipal District, Tasci (2010) stated that in terms of level of income Barnet had a makeup that was different not only from London's other districts but from the rest of England, too. According to the study, Barnet's level of income is higher than the rest of London and the rest of England. It can be surmised that this is why those people living in Mill Hill with its higher than average level of income did not experience any difficulty in adapting to the area's dress culture on moving to London. This conclusion matches the view that a consumer's place of residence influences the products they buy and that people living in the same area tend to make similar purchases (Akyuz, 2006:20).

Observations made in London during the course of the study yielded the impression that middle aged and older people generally wore plain, comfortable clothing with pastel tones so as not to be conspicuous. The younger generations on the other hand boldly wore livelier colors using their 
clothing to express themselves. The young men and women at university wore comfortable jeans with baggy and comfortable sweatshirts. When frequenting the pubs and clubs on Friday evenings and on weekends girls would wear short, flimsy dresses without any thought for the cold air complementing their elegance with high-heeled shoes, altering their attire to fit the time and the venue. It can be said that with this manner of dress they did not experience any problems fitting in with the local English citizens. The findings of this study tend to support these impressions.

The findings relating to the sample group's opinions as to whether or not their manner of dress affected their social lives and how they expressed themselves are presented in Table 15.

Table 15 - Views Concerning How Manner of Dress Affects Social Life

\begin{tabular}{|c|c|c|c|c|c|c|c|c|}
\hline \multirow{2}{*}{ Views } & \multicolumn{2}{|c|}{ Never } & \multicolumn{2}{|c|}{ Sometimes } & \multicolumn{2}{|c|}{ Often } & \multicolumn{2}{|c|}{ Always } \\
\hline & S & $\%$ & S & $\%$ & S & $\%$ & S & $\%$ \\
\hline $\begin{array}{l}\text { a) Manner of dress is an important } \\
\text { element in self-expression. }\end{array}$ & 16 & 4.1 & 60 & 15.2 & 109 & 27.7 & 209 & 53.0 \\
\hline $\begin{array}{l}\text { b) Manner of dress is an important } \\
\text { element in neighborly relations. }\end{array}$ & 112 & 28.4 & 86 & 21.8 & 123 & 31.2 & 73 & 18.5 \\
\hline $\begin{array}{l}\text { c) Manner of dress is an important } \\
\text { element when applying for a job } \\
\text { and when settling into a job. }\end{array}$ & - & - & 41 & 10.4 & 87 & 22.1 & 266 & 67.5 \\
\hline $\begin{array}{c}\text { d) Manner of dress is an important } \\
\text { factor in how people interact with } \\
\text { you. }\end{array}$ & 71 & 18.0 & 73 & 18.5 & 172 & 43.7 & 78 & 19.8 \\
\hline $\begin{array}{l}\text { e) When people dress well they } \\
\text { feel more self-confident. }\end{array}$ & - & - & 57 & 14.5 & 131 & 33.2 & 206 & 52.3 \\
\hline $\begin{array}{l}\text { f) Well-dressed people attract } \\
\text { more attention in all segments of } \\
\text { society. }\end{array}$ & 19 & 4.8 & 84 & 21.3 & 143 & 36.3 & 148 & 37.6 \\
\hline
\end{tabular}

$n=394$

According to Table 16, 53 percent of people acknowledged that manner of dress was "always" an important factor in self-expression, while 27.7 percent said "frequently" and 4.1 percent said "never." This situation can be seen as an example of clothing being a form of communication. Some 31.2 percent said that manner of dress was "frequently" an important factor in neighborly relations while 28.4 percent did not see it as an important factor. Manner of dress was "always" seen as an important factor in job interviews and in settling in at work by 67.5 percent of the sample group. This situation can be seen as an example of clothing being seen as a means of raising status in the workplace. In their study, Yurdakul and Ural (2008:53) determined that attire was 43-percent very influential, 30-percent 
partly influential, 22-percent influential and 5-percent not influential in communicating with other people, and this corroborates our conclusion.

The sample group stated that well-dressed people "frequently" (36.3 percent) or "always" (37.6 percent) drew more attention in every segment of society, and this may be interpreted as manner of dress conferring status. In Ismail's study (2006:92) it can be seen that 38.6 percent of the sample group saw "attire" as a sign of prestige and respect while 29.3 percent were undecided on this. Those findings are similar to the results in Table 16.

Some 52.3 percent of the sample group indicated "always" in response to the view that "when people dress well their self-confidence improves" while 33.2 percent said this was "frequently" the case. According to Aytuglu (2006), self-confidence expresses how a person feels about themselves. A person's self-confidence or lack thereof is the reason why they choose certain products over other products. Choice of clothing is an important factor in social acceptance especially in young adulthood. Being the person one wants to be in outward appearance or wearing the clothes one wants to wear may be influential in increasing a young person's selfconfidence. However, certain social and economic factors can be an obstruction here and in such instances the young people may not be able to fit in. In Koca's study (2008:183) it is stated that there were differences between students' opinions about fashion and the way they followed fashion and that these differences were caused by economic and socio-cultural factors.

\section{Conclusion}

Dress culture is affected by many factors such as geographic location, climate, traditions and customs and attitudes. It is possible to see many differences in dress culture in the same country, the same location, the same city, even the same neighborhood. It was with thought in mind that this study of the dress culture-related adaptation problems encountered by Turkish women living abroad was made. The conclusions arrived at are presented below.

The group that experiences the most problems with respect to dress culture is housewives while students experience the fewest problems. It was also seen that the group aged 50 and over experienced the most problems followed by the group in the 20-25 age bracket. When the effect of income on dress culture adaptation problems was examined it was seen that those people on an income of $£ 1,000$ or less experienced the most hardship adapting.

Those people living in districts like Elephant and Castle, Wood Green and Tottenham, where Turks mainly reside, were seen to experience more adaptation problems than those people living in other areas. It was 
determined that the people living in Mill Hill experienced the fewest problems.

It was determined that a significant proportion of the same group believed that their self-confidence increased when they dressed well and that manner of dress was "always" an important factor in self-expression, applying for a job and in settling into a job.

\section{References:}

1. Akyol, P.(2010), Küreselleşen moda bağlamında blucin kültürü üzerine bir araştırma, Milli Folklor Dergisi, 22 (86), pp.186-196.

2. Akyuz, N(2006), Farkli egitim duzeyindeki kadin tuketicilerin giyim esyasi satin alma davranisları, Yayımlanmamış yüksek lisans tezi, Gazi Universitesi, Egitim Bilimleri Enstitusu, [Unpublished postgraduate thesis, Gazi University, Institute of Educational Sciences Turkey] Ankara.

3. Aktuğlu, Karpat, I. \& Temel, A. (2006) "Markalar nasıl tercih ediliyor? (Kamu sektorü çalışanlarının giysi markalarını tercihini etkileyen faktörlere yönelik bir araştırma), Konya Selçuk Universitesi Sosyal Bilimler Enstitusu Dergisi, Issue:15.

4. Bursaligil, G. (2009), Antropolojik açıdan giyim kültürü, Yüksek lisans tezi, Mimar Sinan Güzel Sanatlar Universitesi, Sosyal Bilimler Enstitüsü,[ Unpublished post-graduate thesis, Mimar Sinan Fine Arts University, Institute of Social Sciences] Istanbul.

5. Demir, N (2006), Oteki Turkiye'de genc kıların medya tüketimi, 2nd International Conference On Women's Studies, Doğu Akdeniz Universitesi, Kuzey Kıbrıs Türk Cumhuriyeti.

6. Ismail, K.(2006), Hazir giyim ürünlerinde markanın tüketici satın alma davranışı üzerine etkileri, Yayımlanmamış yüksek lisans tezi, Gazi Universitesi, Sosyal Bilimler Enstitusu, [Unpublished postgraduate thesis, Gazi University, Institute of Social Sciences Turkey] Ankara.

7. Koca, E., Koç, F., (2016), A Study of Clothing Purchasing Behavior By Gender with Respect to Fashion and Brand Awareness, European Scientific Journal, March 2016 edition, Vol.12, No.7, pp. 234-248

8. Koca, E., Vural, T., Koç, F., (2013), An evaluation of consumer tendencies towards hedonistic shopping for clothes, EJRE-European Journal of Research on Education, Special Issue: Human Resource Management,pp. 54-64

9. Koca, E. (2008). Comparison of viewpoints towards fashion among university students in different countries, Tekstil ve Konfeksiyon, Ege Universitesi Tekstil ve Konfeksiyon Arastirma-Uygulama Merkezi, İzmir, July-September, Vol: 18, Issue:3, pp.174-184. 
10. Koca, E., Koç, F. (2010), Gençlerin dinledikleri müzik türlerinin giyim tarzlarina etkisi, NWSA e-Journal of New World Sciences Academy, 5(2), Article Number: 2C0019, pp.37-49.

11. Koç. F. ( 2008), Socio-cultural evaluation of attitude of the youth against branded clothing, Tekstil ve Konfeksiyon, Ege Universitesi Tekstil ve Konfeksiyon Arastirma-Uygulama Merkezi, İzmir, AprilJune Vol:18, Issue:2, pp.103-114 .

12. Özelge, G. (2008).Islam ve kapitalizim ilişkisi:Türkiye'de 1980 sonrası tüketim kültürü ve tesettür modası.Yüksek lisans tezi, Hacettepe Universitesi, Sosyal Bilimler Enstitüsü, [Unpublished post-graduate thesis, Hacettepe University, Institute of Social Sciences -Turkey] Ankara.

13. Özkan, A. (2006), Kuresellesme Sürecinin Medya ve Kültür Üzerindeki Etkileri, Istanbul: Tasam Publications.

14. Pehlivan, H. (2007), Hepimiz Amerika'da mıYasiyoruz?, Elektronik Sosyal Bilimler Dergisi, www.esosder.org, Vol:6, Issue:22, pp. 270282.

15. Ritzer, G. (1992), Georg Simmel, (Trans.Umit Tatlican), Sociological Theory, Third Edition, McGraw Hill.

16. Taşçı, F. (2010), "Yerel Yonetimlerde Sosyal Politika ve Sosyal Hizmetler: Londra-Barnet Belediyesi Ornegi," Sosyal Siyaset Konferanslari Dergisi, 58. Kitap, pp. 217-251.

17. Yurdakul, S., Ural, Ö (2008), Iletisimde Giyimin Yeri. Endustriyel Sanatlar Egitim Fakultesi Dergisi, 23, pp. 44-54. 